\title{
Uric Acid Level and Its Association with Carotid Intima-Media Thickness in Patients with Cardiac Syndrome X
}

\author{
Nusret Acikgoz Necip Ermis Julide Yagmur Kubra Muezzinoglu \\ Yasin Karakus Mehmet Cansel Hasan Pekdemir Ramazan Ozdemir \\ Department of Cardiology, College of Medicine, Inonu University, Malatya, Turkey
}

\section{Key Words}

Uric acid · Carotid intima-media thickness · Cardiac

syndrome $\mathrm{X}$

\begin{abstract}
Objective: The aim of our study was to evaluate serum uric acid level and its relationship with carotid intima-media thickness (CIMT) in patients with cardiac syndrome X (CSX). Subjects and Methods: A total of 50 patients with CSX (28 females/22 males, $51.0 \pm 10.9$ years) and 40 controls ( $27 \mathrm{fe}-$ males/13 males, $53.0 \pm 10.2$ years) were included in the study. All subjects underwent a noninvasive stress test and conventional coronary angiography. Serum uric acid levels were measured and B mode ultrasonography was performed to assess CIMT in all subjects. Results: Serum uric acid levels were higher in patients with CSX than in the control subjects $(5.1 \pm 1.8$ vs. $3.9 \pm 1.3 \mathrm{mg} / \mathrm{dl} ; \mathrm{p}=0.002)$. The CIMT was higher in patients with CSX than in the control subjects $(0.75 \pm 0.18$ vs. $0.63 \pm 0.09 \mathrm{~mm} ; \mathrm{p}<0.001)$. A significant correlation was found between serum uric acid values and CIMT measurements in patients with CSX $(r=0.666, p<$ $0.001)$. Conclusions: Serum uric acid levels were higher in patients with CSX and elevated serum uric acid levels were
\end{abstract}

associated with carotid atherosclerosis, thereby indicating that elevated serum uric acid levels might contribute to the development of subclinical atherosclerosis in CSX patients.

Copyright $\odot 2011$ S. Karger AG, Basel

\section{Introduction}

Cardiac syndrome $\mathrm{X}$ (CSX) is a clinical entity characterized by angina-like chest pain with a positive response to exercise stress testing and normal coronary angiographic findings $[1,2]$. The exact pathophysiological mechanisms underlying CSX have not been fully elucidated. However, endothelial dysfunction following microvascular ischemia is thought to play a key role in the development of CSX $[3,4]$.

Serum uric acid is known as the final oxidative product of purine catabolism in humans. Several studies have demonstrated that there has been a strong relationship between serum uric acid and atherosclerotic diseases [5-9]. Serum uric acid may contribute to atherosclerosis through several pathways including deleterious effects on endothelial dysfunction, oxidative metabolism, platelet adhesiveness, hemorheology, and platelet aggregation [10-12].

\section{KARGER \\ Fax +4161306 1234 E-Mail karger@karger.ch} www.karger.com
(C) 2011 S. Karger AG, Basel $1011-7571 / 12 / 0212-0115 \$ 38.00 / 0$
Nusret Acikgoz

Department of Cardiology, College of Medicine, Inonu University

Malatya (Turkey)

Tel. +904223410660

E-Mail nusretacikgoz@hotmail.com 
Increased serum uric acid level may play a role in the pathological processes of CSX and so, we aimed to investigate serum uric acid level and its relationship to carotid intima-media thickness (CIMT) in patients with CSX.

\section{Subjects and Methods}

\section{Study Population}

Fifty patients with CSX (28 females/22 males, $51.0 \pm 10.9$ years, range 28-73) and 40 controls (27 females/13 males, $53.0 \pm$ 10.2 years, range $31-72)$ ]were included in the study. The diagnosis of CSX was based on the presence of typical effort angina, transient ischemic ST-segment depression $(\geq 1 \mathrm{~mm})$ during the treadmill exercise test and angiographically normal coronary arteries. The control patients consisted of individuals who had chest discomfort, negative treadmill test and angiographically normal coronary arteries and whose age, sex and coronary artery disease risk factors were similar to those of the patients with CSX.

Exclusion criteria included acute coronary syndrome, valvular heart disease, left ventricular hypertrophy, atrial fibrillation, cardiomyopathy, pericarditis, congenital heart disease, heart failure, renal and hepatic failure, acute and chronic inflammatory diseases, anemia, gout, malignancy, immunological disease, hormone replacement therapy, history of diuretic use and excessive alcohol consumption. The study was approved by the institution's Ethics Committee and written informed consent was obtained from all participants of this study.

\section{Carotid Ultrasonography}

B mode carotid ultrasonography was performed to assess CIMT in all subjects, using a high-frequency ultrasound system (HDI-5000; ATL, Bothell, Wash., USA) and a 7- to 10-MHz linear array transducer. Both common and internal carotid arteries and carotid bulbi were examined morphologically in detail in all patients. We used zoom window for measurement. The region where CIMT was measured was $1 \mathrm{~cm}$ proximal to the carotid bifurcation, for both common carotid arteries. The CIMT was measured as the distance from the intima-luminal interface to the mediaadventitial interface within the far wall. CIMT was calculated as the average of 10 measurements, for both common carotid arteries. All measurements were obtained by a single observer (K.M.), who was blinded to the clinical status of the patients, and the intraobserver variability of ultrasonographic measurements was $<3 \%$.

\section{Treadmill Exercise Stress Test}

Treadmill exercise test was conducted according to the modified Bruce protocol (T600 Treadmill, Spacelabs Burdick, Inc. Wisc., USA). All participants were requested to avoid food, alcohol, caffeine, or smoking at least $3 \mathrm{~h}$ before the test. During the test, the heart rate, ECG, and blood pressure values of all participants were recorded and all participants were continuously monitored using three ECG leads (V2, V5 and aVF). A positive treadmill test was defined as the presence of $\geq 1.0 \mathrm{~mm}$ horizontal or downsloping ST-segment depression at $80 \mathrm{~ms}$ from the J point during the test.

\section{Coronary Angiography}

Coronary angiography was performed using standard Judkins technique without the use of nitroglycerin in all subjects (Philips Medical Systems Integris H 3500 ve 5000). Normal coronary arteries were defined as having no visible luminal narrowing or irregularity. During coronary angiography, to exclude the possibility of coronary artery vasospasm, all patients underwent a hyperventilation test, which was performed by asking the patients to breathe quickly and deeply for $5 \mathrm{~min}$. The angiographic analysis was performed by 2 observers (E.A., H.T.) independently blinded to the clinical details of the study and any disagreement was resolved by consensus.

\section{Biochemical Measurements}

Blood samples were obtained from the cannulated antecubital vein in serum tubes at 08.00-10.00 a.m. following an overnight fasting period. Serum uric acid levels were measured with enzymatic colorimetric method using an Abbott-Architect autoanalyzer (Abbott Laboratory, Abbott Park, Ill., USA). The normal reference ranges in our laboratory for serum uric acid for women and men were $2.6-6$ and $3.5-7.2 \mathrm{mg} / \mathrm{dl}$, respectively. The other biochemical analyses were determined by standard methods.

\section{Statistical Analysis}

Statistical analysis was performed using SPSS software package, version 17.0 (SPSS Inc., Chicago, Ill., USA). All continuous variables were expressed as mean \pm standard deviation and categorical variables were expressed as numbers. For continuous variables unpaired Student's t test and for categorical changes Pearson's $\chi^{2}$ test were used. The correlations between serum uric acid levels and other variables were evaluated by the Pearson's correlation test. Statistical significance was accepted as $p$ value $<0.05$.

\section{Results}

Baseline clinical characteristics and laboratory findings are given in table 1 . There was no statistically significant difference between the patients with CSX and the control subjects regarding age, sex, smoking, body mass index, systolic and diastolic blood pressure, glucose, cholesterol and creatinine levels. None of the patients exhibited any visible luminal narrowing or irregularities on coronary angiograms.

Serum uric acid levels were higher in patients with CSX than in the control subjects $(5.1 \pm 1.8$ vs. $3.9 \pm 1.3$ $\mathrm{mg} / \mathrm{dl} ; \mathrm{p}=0.002$, fig. 1 ). The normal values of CSX and control groups for serum uric acid levels were 66 and 75\%, respectively. The highest quartile of the CSX group was $28 \%$ and that of the control group was $32 \%$. The CIMT was higher in patients with CSX than in the control subjects $(0.75 \pm 0.18$ vs. $0.63 \pm 0.09 \mathrm{~mm} ; \mathrm{p}<0.001)$. There was a significant correlation between serum uric acid values and CIMT measurements in patients with CSX ( $\mathrm{r}=$ $0.666, \mathrm{p}<0.001$, fig. 2). 


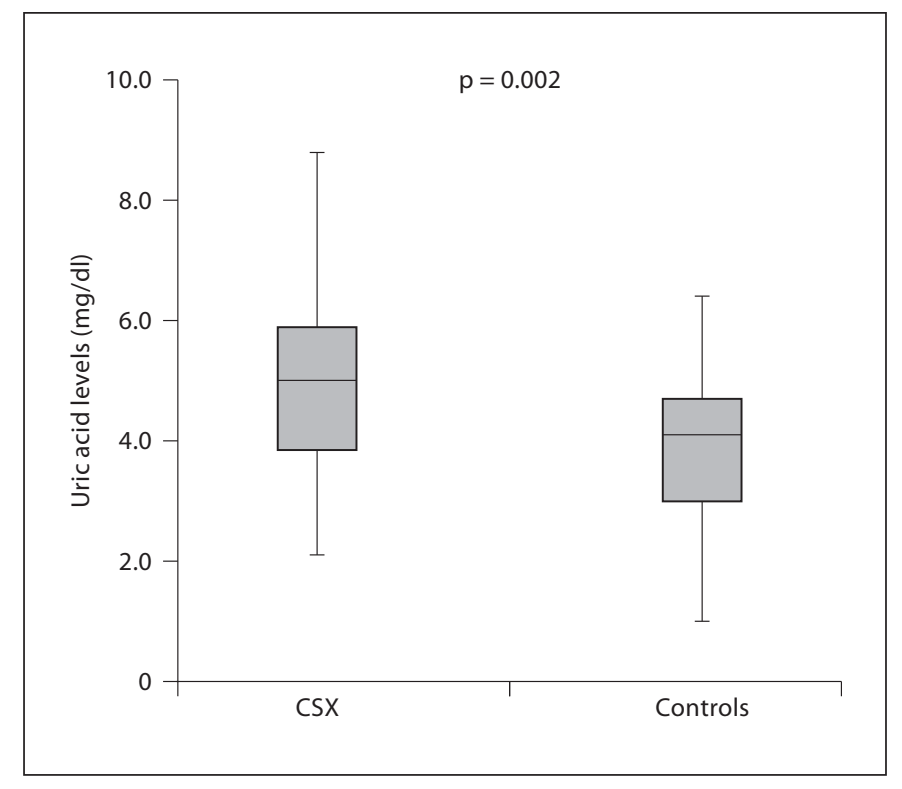

Fig. 1. Serum uric acid levels in patients with CSX and controls $($ mean $\pm \mathrm{SD})$.

\section{Discussion}

In this study, the serum uric acid levels were significantly higher in patients with CSX than in the control subjects $(\mathrm{p}=0.002)$ and also there was a strong correlation between serum uric acid levels and CIMT measurements. These results may indicate that elevated serum uric acid levels are associated with the atherosclerotic process of CSX.

The exact pathophysiological mechanisms underlying CSX are not fully understood. However, endothelial dysfunction leading to microvascular angina and impaired coronary flow reserve have been proposed as the main pathogenetic mechanisms $[3,4,13]$. Cox et al. [14] demonstrated the presence of endothelial dysfunction and subangiographic atheroma in patients with CSX. Abnormal coronary arteries with atheromatous plaques and intimal thickening have been observed by intravascular ultrasonographic studies in patients with CSX [14, 15].

Several studies have demonstrated an association between serum uric acid level and atherosclerosis [5-9]. Patetsios et al. [16] have found uric acid to be present in increased amounts in atherosclerotic plaque and they postulated that it might have played a role in the development of atherosclerosis. Moreover, previous studies [17-19] have shown that uric acid is associated with many risk factors for coronary artery disease, such as hypertension, hyperlipidemia, diabetes mellitus and obesity. There may

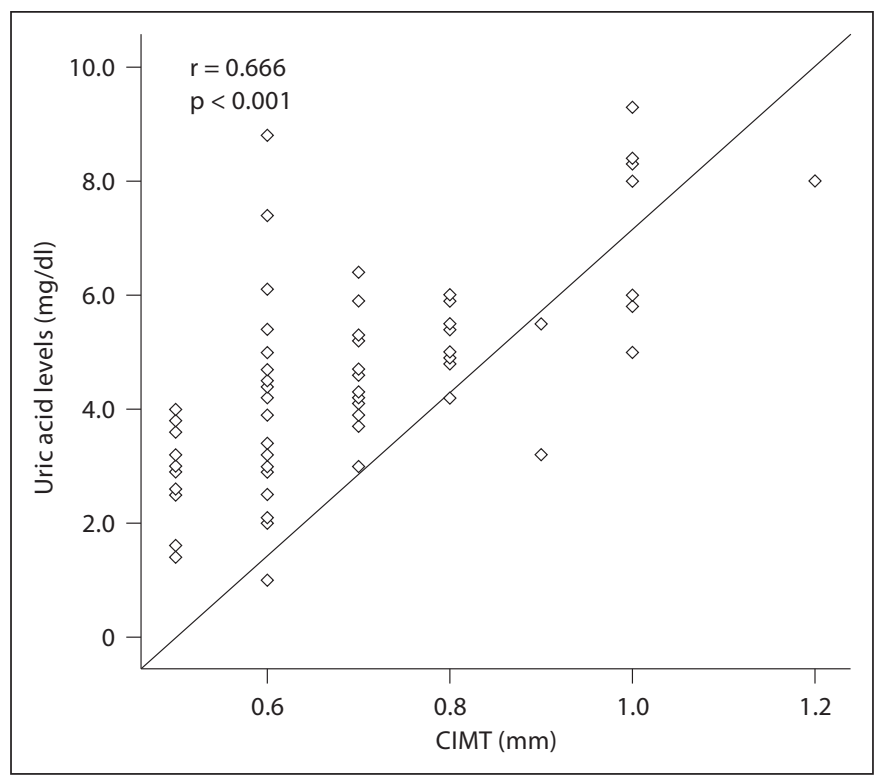

Fig. 2. Relationship between serum uric acid levels and CIMT in patients with CSX.

Table 1. Comparison of clinical characteristics and laboratory findings of the study population

\begin{tabular}{lccc}
\hline & $\begin{array}{l}\text { CSX } \\
(\mathrm{n}=50)\end{array}$ & $\begin{array}{l}\text { Controls } \\
(\mathrm{n}=40)\end{array}$ & $\begin{array}{l}\mathrm{p} \\
\text { value }\end{array}$ \\
\hline Age, years & $51.0 \pm 1.9$ & $53.0 \pm 10.2$ & 0.38 \\
Females/males & $28 / 22$ & $27 / 13$ & 0.27 \\
Smokers & 12 & 11 & 0.70 \\
Body mass index, kg/m ${ }^{2}$ & $28.0 \pm 4.0$ & $27.1 \pm 4.5$ & 0.33 \\
Systolic BP, mm Hg & $124.0 \pm 13.5$ & $121.9 \pm 15.3$ & 0.50 \\
Diastolic BP, mm Hg & $77.7 \pm 10.5$ & $74.6 \pm 13.6$ & 0.25 \\
Glucose, mg/dl & $99.9 \pm 15.7$ & $100.2 \pm 15.2$ & 0.93 \\
Total cholesterol, mg/dl & $200.3 \pm 39.8$ & $191.2 \pm 38.2$ & 0.29 \\
LDL cholesterol, mg/dl & $125.0 \pm 31.6$ & $119.3 \pm 34.5$ & 0.43 \\
HDL cholesterol, mg/dl & $41.8 \pm 9.1$ & $43.2 \pm 8.8$ & 0.46 \\
Triglyceride, mg/l & $159.2 \pm 75.1$ & $144.4 \pm 70.3$ & 0.36 \\
Creatinine, mg/dl & $0.83 \pm 0.16$ & $0.78 \pm 0.17$ & 0.15 \\
Serum uric acid, mg/dl & $5.1 \pm 1.8$ & $3.9 \pm 1.3$ & 0.002 \\
Intima-media thickness, mm & $0.75 \pm 0.18$ & $0.63 \pm 0.09$ & $<0.001$ \\
\hline & & &
\end{tabular}

$\mathrm{BP}=$ Blood pressure; $\mathrm{LDL}=$ low-density lipoprotein; $\mathrm{HDL}=$ high-density lipoprotein.

be several mechanisms by which uric acid is associated with atherosclerotic disease. Uric acid promotes the activation of endothelial cells, platelet activation and increased platelet adhesiveness [12, 20, 21]. Furthermore, uric acid stimulates vascular smooth muscle prolifera- 
tion and up-regulates the expression of platelet-derived growth factor and monocyte chemoattractant protein 1 $[22,23]$. Additionally, animal studies have shown that experimental hyperuricemia may cause endothelial dysfunction through decreased nitric oxide production [24]. In our study, we found that serum uric acid levels were higher in patients with CSX than in the controls.

CIMT is measured noninvasively by ultrasonography and is a well-established index of early-stage atherosclerosis $[25,26]$. Our finding that CIMT is increased in patients with CSX in spite of angiographically normal coronary arteries confirms these previous findings [27, 28]. It also confirms the reports of Cox et al. [14] and Wiedermann et al. [15] regarding the presence of subangiographic atheroma in CSX patients and therefore emphasizes the limitations of coronary angiography in detecting early signs of atherosclerosis, such as intima-media thickening.

\section{Study Limitations}

The main limitation of our study was the comparatively small size of the study population. Another limita- tion was the possibility of any underlying coronary artery spasm in patients with CSX, which was ruled out by a hyperventilation test despite the superiority of the ergonovine test. Finally, we did not assess insulin resistance in our study. It is believed that there is a relationship between serum uric acid levels and insulin resistance. If we had assessed insulin resistance in our study, we could have ruled out insulin resistance as a possible conofounder.

\section{Conclusion}

Serum uric acid levels were significantly higher in patients with CSX than in the control subjects and there was a strong correlation between elevated serum uric acid levels and increased CIMT. Hence, elevated serum uric acid levels might play a role in the pathological process of CSX and allopurinol might be beneficial in the treatment of patients with CSX.

\section{References}

1 Crea F, Lanza GA: Angina pectoris and normal coronary arteries: cardiac syndrome X. Heart 2004;90:457-463.

$\checkmark 2$ Kaski JC: Pathophysiology and management of patients with chest pain and normal coronary arteriograms (cardiac syndrome $\mathrm{X}$ ). Circulation 2004;109:568-572.

>3 Hurst T, Olson TH, Olson LE, Appleton CP: Cardiac syndrome $\mathrm{X}$ and endothelial dysfunction: new concepts in prognosis and treatment. Am J Med 2006;119:560-566.

4 Egashira K, Inou T, Hirooka Y, Yamada A, Urabe Y, Takeshita A: Evidence of impaired endothelium-dependent coronary vasodilatation in patients with angina pectoris and normal coronary angiograms. N Engl J Med 1993;328:1659-1664.

5 Fang J, Alderman MH: Serum uric acid and cardiovascular mortality the NHANES I epidemiologic follow-up study, 1971-1992. National Health and Nutrition Examination Survey. JAMA 2000;283:2404-2410.

6 Alderman MH, Cohen H, Madhavan S, Kivlighn S: Serum uric acid and cardiovascular events in successfully treated hypertensive patients. Hypertension 1999;34:144-150.

77 Brand FN, McGee DL, Kannel WB, Stokes J, Castelli WP: Hyperuricemia as a risk factor of coronary artery disease: the Framingham study. Am J Epidemiol 1985;121:11-18.
-8 Iribarren C, Folsom A, Eckfeldt J, McGovern $\mathrm{P}$, Nieto J: Correlates of uric acid and its association with asymptomatic carotid atherosclerosis: the ARIC Study. Ann Epidemiol 1996;6:331-340.

$\checkmark 9$ Lehto S, Niskanen L, Ronnemaa T, Laasko $\mathrm{M}$ : Serum uric acid is a strong predictor of stroke in patients with non-insulin-dependent diabetes mellitus. Stroke 1998;29:635663.

10 Butler R, Morris AD, Belch JJ, Hill A, Struthers AD: Allopurinol normalizes endothelial dysfunction in type 2 diabetics with mild hypertension. Hypertension 2000;35: 746-751.

11 Kang DH, Nakagawa T, Feng L, Watanabe S, Han L, Mazzali M, Truong L, Harris R, Johnson RJ: A role for uric acid in the progression of renal disease. J Am Soc Nephrol 2002;13: 2888-2897.

12 Johnson RJ, Kang DH, Feig D, Kivlighn S, Kanellis J, Watanabe S, Tuttle KR, Rodriguez-Iturbe B, Herrera-Acosta J, Mazzali M: Is there a pathogenetic role for uric acid in hypertension and cardiovascular and renal disease? Hypertension 2003;41:1183-1189.

13 Legrand V, Hodgson JM, Bates ER, Aueron FM, Mancini GB, Smith JS, Gross MD, Vogel RA: Abnormal coronary flow reserve and abnormal radionuclide exercise test results in patients with normal coronary angiograms. J Am Coll Cardiol 1985;6:1245-1253. $\checkmark 14$ Cox ID, Clague JR, Bagger J, Ward DE, Kaski JC: Endothelial dysfunction, subangiographic atheroma, and unstable symptoms in patients with chest pain and normal coronary arteriograms. Clin Cardiol 2000;23: 645-652.

15 Wiedermann JG, Schwartz A, Apfelbaum M: Anatomic and physiologic heterogeneity in patients with syndrome $\mathrm{X}$ : an intravascular ultrasound study. J Am Coll Cardiol 1995;25: 1310-1317.

16 Patetsios P, Song M, Shutze WP, Pappas C, Rodino W, Ramirez JA, Panetta TF: Identification of uric acid and xanthine oxidase in atherosclerotic plaque. Am J Cardiol 2001; 88:188-191.

17 Klein R, Klein BE, Cornoni JC, Maready J, Cassel JC, Tyroler HA: Serum uric acid: its relationship to coronary heart disease risk factors and cardiovascular disease, Evans County, Georgia. Arch Intern Med 1973;132: 401-410.

18 Klein BE, Klein R, Lee KE: Components of the metabolic syndrome and risk of cardiovascular disease and diabetes in Beaver Dam. Diabetes Care 2002;25:1790-1794.

19 Lee J, Sparrow D, Vokonas PS, Landsberg L, Weiss ST: Uric acid and coronary heart disease risk: evidence for a role of uric acid in the obesity-insulin resistance syndrome. The Normative Aging Study. Am J Epidemiol 1995; 142:288-294. 
-20 Lippi G, Montagnana M, Franchini M, Favaloro EJ, Targher G: The paradoxical relationship between serum uric acid and cardiovascular disease. Clin Chim Acta 2008; 392:1-7.

-21 Kanellis J, Kang DH: Uric acid as a mediator of endothelial dysfunction, inflammation, and vascular disease. Semin Nephrol 2005; 25:39-42.

-22 Rao GN, Corson MA, Berk BC: Uric acid stimulates vascular smooth muscle cell proliferation by increasing platelet-derived growth factor A-chain expression. J Biol Chem 1991;266:8604-8608.
23 Kanellis J, Watanabe S, Li JH, Kang DH, Li P, Nakagawa T, Wamsley A, Sheikh-Hamad D, Lan HY, Feng L, Johnson RJ: Uric acid stimulates monocyte chemoattractant protein-1 production in vascular smooth muscle cells via mitogen-activated protein kinase and cyclooxygenase-2. Hypertension 2003;41: 1287-1293.

24 Mazzali M, Kanellis J, Han L, Feng L, Xia YY, Chen Q, Kang DH, Gordon KL, Watanabe S, Nakagawa T, et al: Hyperuricemia induces a primary arteriolopathy in rats by a blood pressure-independent mechanism. Am J Physiol Renal Physiol 2002;282:F991-F997.

-25 de Groot E, Hovingh GK, Wiegman A, Duriez P, Smit AJ, Fruchart JC, Kastelein JJ: Measurement of arterial wall thickness as a surrogate marker for atherosclerosis. Circulation 2004;109:(suppl 1):III33-III38.
6 Kotani K, Koibuchi H, Miyamoto M, Yamada T, Taniguchi N: Relationship between reactive oxygen metabolites and carotid intima-media thickness in subjects with hypercholesterolemia. Med Princ Pract 2010;19: 496-498.

27 Arroyo-Espliguero R, Mollichelli N, Avanzas P, Zouridakis E, Newey VR, Nassiri DK, Kaski JC: Chronic inflammation and increased arterial stiffness in patients with cardiac syndrome X. Eur Heart J 2003;24:20062011.

-28 Sen N, Poyraz F, Tavil Y, Yazici HU, Turfan M, Hizal F, Topal S, Erdamar H, Cakir E, Yalçin R, et al: Carotid intima-media thickness in patients with cardiac syndrome $\mathrm{X}$ and its association with high circulating levels of asymmetric dimethylarginine. Atherosclerosis 2009;204:82-85. 